\title{
The Effect of Light-Emitting Diodes Illumination Period and Light Intensity on High Rate Algal Reactor System in Laundry Wastewater Treatment
}

\author{
Bieby Voijant Tangahu' ${ }^{1}$ Adhi Triatmojo ${ }^{1}$, Ipung Fitri Purwanti', \\ Setyo Budi Kurniawan ${ }^{1 *}$
}

1 Department of Environmental Engineering, Faculty of Civil, Environmental and Geo Engineering, Institut Teknologi Sepuluh Nopember, Jalan Raya ITS, Kampus ITS Sukolilo, Surabaya 60111, Indonesia

* Corresponding author's e-mail: setyobudi.kurniawan@gmail.com

\begin{abstract}
Wastewater that contains high concentration of nutrients can create instability in water ecosystem if left untreated. Laundry wastewater contains nutrients in high concentration. The nutrients that commonly found in laundry wastewater are nitrogen and phosphorus. This study had a purpose to determine the effect of illumination period and light intensity for the removal of Chemical Oxygen Demand (COD), Nitrogen-ammonia ( $\left.\mathrm{NH}_{3}-\mathrm{N}\right)$, and phosphate (P) content using Chlorella vulgaris in High Rate Algal Reactor (HRAR) treatment. Variables that used were exposure period of 12 and 24 hours and light intensity of 2000-3000 Lux, 4000-5000 Lux, and 6000-7000 lux. The parameters tested to determine the efficiency of nutrient removal were COD, Nitrogen-ammonia, phosphate and Chlorophyll $\alpha$ to determine the condition of algae development. The results showed that the highest nutrient removal were obtained by the reactor with 24 hours illumination period with light intensity of 6000-7000 Lux that was capable of removing $54.63 \%$ of COD, and $22.15 \%$ of $\mathrm{P}$. The 12 -hour illumination period was better in terms of $\mathrm{NH}_{3}-\mathrm{N}$ removal, up to $50.07 \%$. On the basis of the of statistic test result, the illumination period did not significantly influence the removal efficiency of $\mathrm{COD}, \mathrm{NH}_{3}-\mathrm{N}$ and $\mathrm{P}$ indicated by $\mathrm{P}$-value $>0.05$, while the light intensity significantly affect the removal of $\mathrm{COD}$ and $\mathrm{NH}_{3}-\mathrm{N}$ showed by $\mathrm{P}$ value $<0.05$.
\end{abstract}

Keywords: Algae, C. vulgaris, Laundry Wastewater, Illumination Period, Light-Emitting Diodes, Light Intensity, Microalgae.

\section{INTRODUCTION}

In large quantities, laundry wastewater can lead to eutrophication and algal blooming if left untreated [Tectona, 2011]. Laundry waste is one of the causes of algl blooming in water bodies because it has high organic content and nutrient concentrations if not controlled properly [Kurniawan et al., 2018]. One of the souces of wastewater containg high nutrient is the laundry industry. About 15 litres of clean water is needed for laundry industry to wash $1 \mathrm{~kg}$ of clothes. On average, the laundry industry washes $25 \mathrm{~kg}$ of clothes per day, producing high nutrient containing wastewater of about 400 litres/day [Ciabatti et al., 2009].
High Rate Algal Reactor (HRAR) is one of wastewater treatment systems using microalgae. This treatment aims to reduce the high nutrient contents from wastewater [Rawat et al., 2010]. In HRAR wastewater treatment, simbiotic relation between the heterotroph bacteria and microalgae cell that live in the water were used to remove pollutants [Hamouri., 2008]. The biological reaction in HRAR can reduce the organic and nutrient content in wastewater through decomposition by bacteria and nutrient conversion to microalgae biomass using the photosyntetic process [Polpraset, 1996; Purwanti et al., 2018]. HRAR is operated at average speed of $10-30 \mathrm{~cm} /$ sec to avoid sedimentation from microalgae cell [Fallowfield and Garret, 1985]. 
The assimilation of $\mathrm{N}$ by algae and floating aquatic plants accounted for about $65 \%$ of the total $\mathrm{N}$ removal, ammonia volatilization of $15 \%$ and about $20 \%$ of total removal in $\mathrm{N}$ content can be assumed based on the nitrification-denitrification process [Mostret and Grobbelar, 1987]. According to [Wang et al., 2010] the research with specific use of algae may allow for greater nutrient removal, in addition to specific species biomass byproducts for various purposes. Chlorella $S p$. is a type of algae that has high tolerance levels of pollutants andis easy to obtain; hence, Chlorella $S p$. is often used in wastewater treatment [Man et al., 2016].

According to our knowledge, the research on laundry wastewater treatment using HRAR system has not been widely conducted. The purpose of this study was to obtain the removal of nutrient content in laundry wastewater by using High Rate Algal Reactor (HRAR). Variation of the illumination period and light intensity were used to measure the removal efficiency of nutrient content, and the development of alga yielded. HRAR were performed at 6 days of retention time with variation of illumination period were 12 and 24 hours and variation of light intensity were 2000-3000 Lux, 4000-5000 Lux, and 6000-7000 Lux, This variation was chosen to understand the impact of light and dark reaction towards microalgae. The parameters used in this research were Chemical Oxygen Demand (COD), nitrogen-ammonia (NH3-N), and phosphate (P). Chlorophyll $\alpha$ will also be analyzed to comprehend the microalgae development. The removal efficiencies of each reactor were calculated by comparing the result of parameters analysis, before and after treatment process using HRAR.

\section{MATERIALS AND METHODS}

At the beginning of research, the COD, nitrogen ammonia $\left(\mathrm{NH}_{3}-\mathrm{N}\right)$, and phosphate $(\mathrm{P})$ content in laundry wastewater was analysed. Sampling was carried out in Keputih District, Sukolilo, Surabaya, Indonesia using integrated sample method on 4 different laundries. The results showed that the $\mathrm{COD}, \mathrm{NH}_{3}-\mathrm{N}$ and $\mathrm{P}$ values ranged between $600-829 \mathrm{mg} / \mathrm{L}, 4.96-8.66$ and $8.53-12.62 \mathrm{mg} / \mathrm{L}$, respectively. $\mathrm{NH}_{3}-\mathrm{N}$ was analysed using Nessler Method. Phosphate in the orthophosphate form was analysed using 4500-PStannous Chloride Method and the COD analysis was performed by using close reflux method.
This experiment used 6 reactor containers consisting of 3 test reactors and 3 control reactors. The volumes of the employed reactors were \pm 12 Liters by $30 \mathrm{~cm}$ diameter and $27 \mathrm{~cm}$ height. The lighting sources included 18 watts Light Emitting Diodes (LED) (Phillips, Indonesia). The light intensity was measured using Lux Meter (HS1010, Indonesia) on the surface of the reactor. The algae used in this study was Chlorella vulgaris that were previously filtered with $50 \mu$ cloth filter to harvest microalgae with $94 \pm 2 \%$ efficiency [Bejor et al., 2013].

Chlorella vulgaris was illuminated by LED with a variety of light intensities, i.e. 2000-3000 Lux, 4000-5000 Lux, and 6000-7000 Lux. The reactor retention time was 6 days with constant agitation by 12 or 24 hours of illumination period. The removal efficiencies of each reactor were analysed through the removal of $\mathrm{COD}, \mathrm{NH}_{3}-\mathrm{N}$, and $\mathrm{P}$ parameters. Chlorophyll $\alpha$ was also analysed to understand the microalgae development under different conditions.

\section{RESULTS AND DISCUSSION}

\section{Nitrogen-Ammonia removal}

The light intensity experiment showed that 6000-7000 Lux was adequate for the algal growth. This observation was in line with [Ifeanyi et al., 2011] who reported that the light with higher intensity can boost the growth of algae. The growth of algae in a reactor can affect the HRAR nutrient removal efficiency [Mirquez et al., 2016], the higher light intensity, the higher of microalgae concentration, resulting in the better removal efficiency. The rate of ammonia removal in all batch reactors increased at higher light intensity, as showed in Figures 1 and 2. The effect of the illumination time was presented in Figures 3 and 4. A linear correlation between chlorophyll $\alpha$ and ammonia concentration in the reactor was also observed. It is suggested that ammonia was consumed by microalgae.

It can be seen that the ammonia content always decreases, but on day 3 and 4 ammonia increases again; afterwards, the trend on the next day continues to fall. This case occurred because some of the microalgae present in the reactor begin to die and decompose, thus releasing the nitrogen back into the reactor in the $3^{\text {rd }}$ and $4^{\text {th }}$ days. The optimum removal efficiency was obtained in the reactor with 6000-7000 Lux lighting, which is 50\%, while the 4000-5000 Lux and 2000-3000 


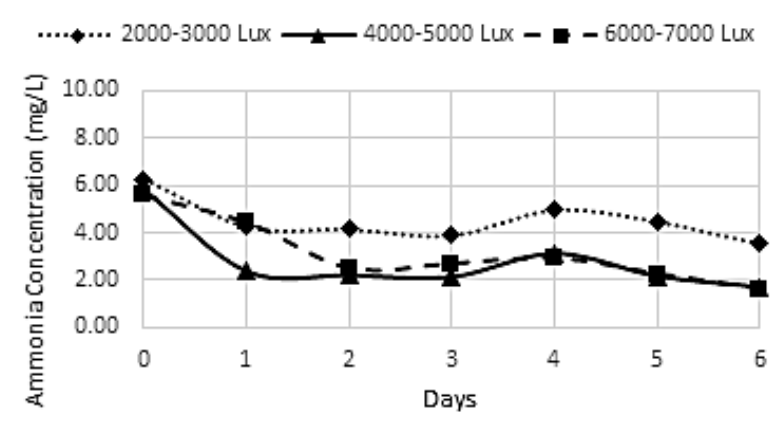

Figure 1. HRAR ammonia trend against light intensity

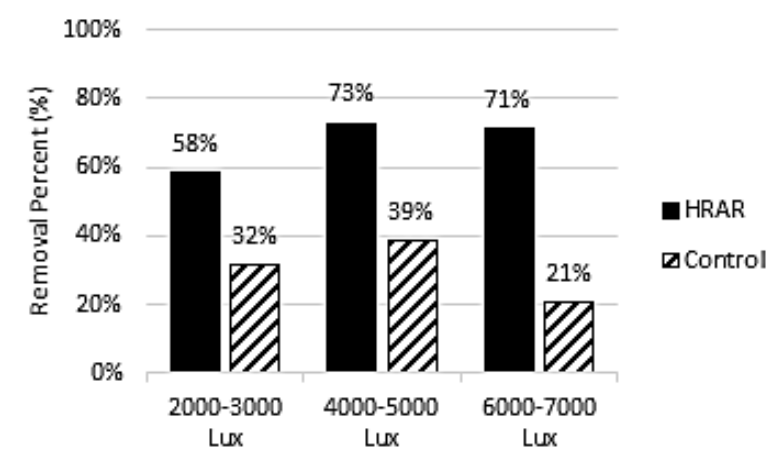

Figure 2. HRAR ammonia removal against light intensity

Lux reactors have $32 \%$ and $26 \%$ removal efficiencies, respectively. The control reactor has a lower efficiency than the reactor containing microalgae. The range of removal at the control reactor ranged from $21-39 \%$, while the reactor containing microalgae showed that the $\mathrm{NH}_{3}-\mathrm{N}$ removal ranged from $58-73 \%$.

On the basis of Figures 3 and 4, the optimum $\mathrm{NH}_{3}-\mathrm{N}$ removal efficiency was the same in all illumination period, which was $71 \%$. This case indicated that the illumination time did not have a significant effect on the nitrogen removal. Different removal efficiencies was obtained on day 4 , which amounted to $50.05 \%$ for 12 hours and $46.65 \%$ for 24 hours of illumination time. This result also suggests that the uptake of microalgae greatly affects the $\mathrm{NH}_{3}-\mathrm{N}$ removal process, because in general, ammonia was the easiest nitrogen source to be taken up by microalgae [Garcia et al., 2000].

\section{Phosphate removal}

While correlating the removal percentage of phosphate with light intensity, the correlation coefficients were low, as we can see at Figures 5 and 6. This suggested that apart from the uptake by microalgae, other factors of have also played

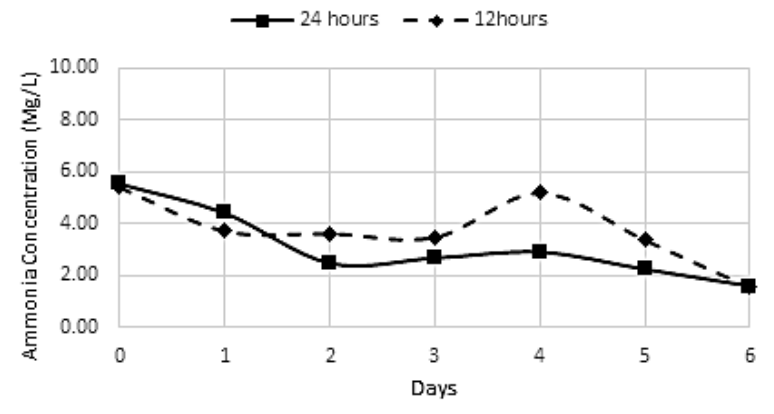

Figure 3. HRAR ammonia trend against illumination period

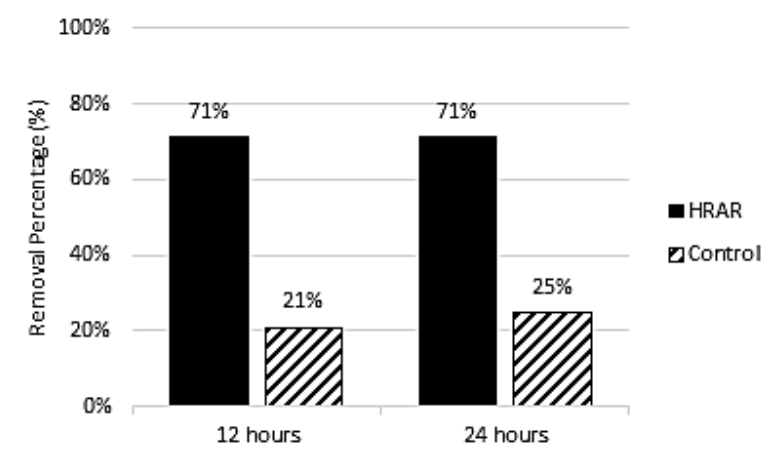

Figure 4. HRAR ammonia removal against illumination period

a certain role. The mechanism that was important in the reduction of phosphate concentration was immobilization in the sediment with the precipitation of phosphorus-calcium and uptake bonds by microalgae [Chen et al., 2003].

Figure 5 showed that the overall phosphate concentration is decreasing. The phosphate concentration in the reactor tends to fluctuate, which is caused by microalgae excretion as a part of their metabolism [Vymazal, 1995]. On the basis of the Figure 6 it can be noticed that the reactor with 4000-5000 Lux had a removal of 30\%, while $6000-7000$ Lux had $27 \%$. The reactor with 2000-3000 Lux had the lowest percentage of removal, which was $7 \%$. The removal efficiency at the control reactor has the greatest removal efficiency, ranging from 19 to $36 \%$. The phosphate removal was smaller when compared to $\mathrm{NH}_{3}-\mathrm{N}$ because the required $\mathrm{C}: \mathrm{N}$ : $\mathrm{P}$ ratio for microalgae growth is 106: 16: 1 [Chen et al., 2003]; thus, the phosphate uptake by microalgae will be smaller. Figures 7 and 8 show that the reactor with 12 hours of illumination period had $22.14 \% \mathrm{P}$ removal, while 24 hours of illumination period had $13.24 \%$ removal. The results of the statistical analysis showed that the illumination period significantly affected the removal of phosphate in reactors. 


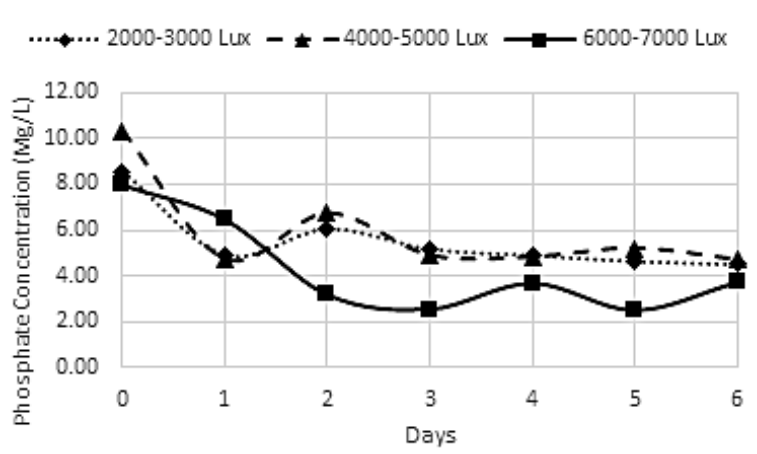

Figure 5. HRAR phosphate trend against light intensity

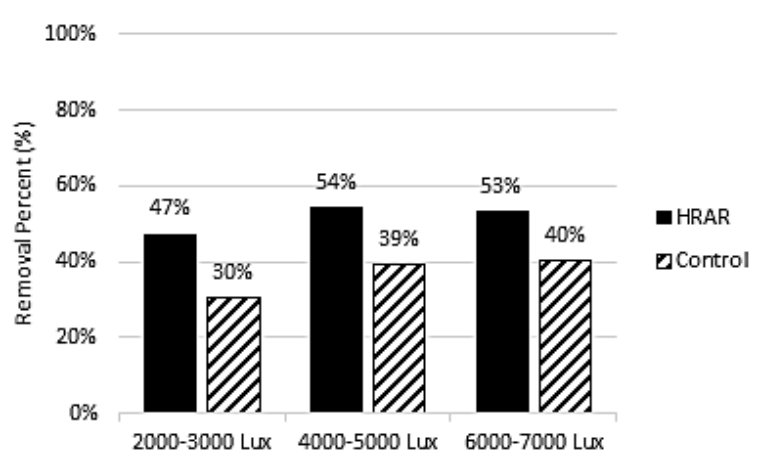

Figure 6. HRAR phosphate removal against light intensity

\section{Chemical Oxygen Demand removal}

The correlation between the COD removal and light intensity were linear as shown in Figures 9 and 10. In the reactor with 2000-3000 Lux, the trend of COD concentration continues to decline and tend to be stable until the end of test period. In the reactor with 4000-5000 Lux and 6000-7000 Lux, the COD concentration increases occurred on days 2 and to 3 . The fluctuations in the concentration occurred due to the decomposition of dead microalgae, counted as organic substances dissolved in wastewater. According to Figures 9

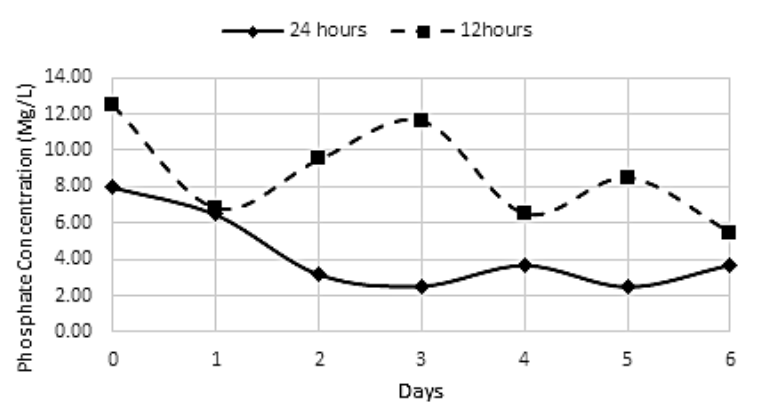

Figure 7. HRAR phospate trend against illumination period

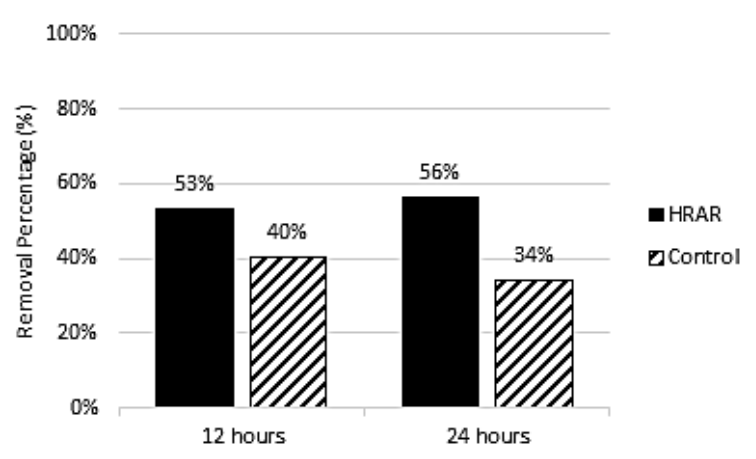

Figure 8. HRAR phospate removal against illumination period

and 10 , the greater the intensity of light, the higher the percentage of COD removal. This resulted from the control of the amount of light in lightdark cycle of algal metabolism. This cycle will break the organic substances down into simpler compounds and provide energy for metabolism.

The Chemical Oxygen Demand and illumination period had a linear correlation, as shown in Figure 11 and Figure 12. In the 12 hours of illumination period, the trend of COD concentration continues to decline and tends to be stable until the end of test period, In the 24 hours of illumination period, a concentration increase also

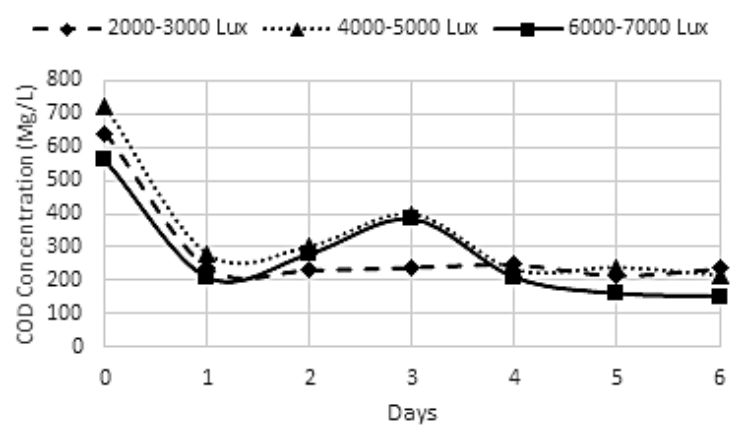

Figure 9. HRAR COD trend against light intensity

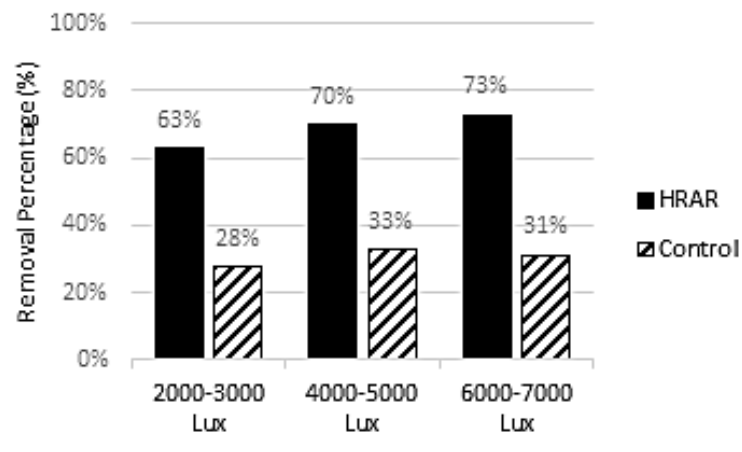

Figure 10. HRAR COD removal against light intensity 
occurred on days 2 to 3 , with the same reason suggested as the cause. Figure 11 showed that the 12 and 24 hours of illumination period had 55\% and $42 \%$ removal percentages, respectively. The illumination period did not significantly affect the percentage of COD removal. This occurred due to the total of light intensity that actually affects the COD removal, not the illumination time. The light intensity was controlling the light-dark cycle in the algal metabolism to break the organic substances down, which resulted in COD reduction.

\section{CONCLUSIONS}

The illumination period had no significant effect on any of the parameters of the study. The largest removal percentage for COD is $54.62 \%$, and Phosphate is $22.14 \%$ with light period exposure of 24 hours while $\mathrm{NH}_{3}-\mathrm{N}$ was $50.07 \%$ with 12 hours of illumination period. Contrary to the illumination period, the light intensity had a significant effect on the removal of $\mathrm{NH}_{3}-\mathrm{N}$ and COD. However, the phosphate removal was not significantly affected by light intensity. The largest removal percentage for COD was $55 \%$, and for $\mathrm{NH}_{3}-\mathrm{N}$ it amounted to $46 \%$ with $6000-7000$ Lux of light intensity, while phosphate had 30\% removal in the reactor with 4000-5000 Lux light intensity.

\section{Acknowledgements}

Authors would like to thank LPPM ITS for their financial support. In addition, we are grateful to the Department of Environmental Engineering, FTSLK, Institut Teknologi Sepuluh Nopember for their technical cooperation and the provision of chemical compounds.

\section{REFERENCES}

1. Bejor E.S., C. Mota, N.M. Ogarekpe, K.U. and Emerson, J. Ukpata. 2013. Low-Cost Harvesting of Microalgae Biomass from Water. International Journal of Development and Sustainability, 2 (1), 1-11.

2. Chen. P., Zhou, Q., Paing, J., Le, H. and Picot, B. 2003. Nutrient Removal by Integrated use of High Rate Algal Ponds and Macrophytes system in China. Water Science and Technology, 48(2), 251-257.

3. Ciabatti, I. F., L. Faralli, E. Fatrella and F. Togotti.

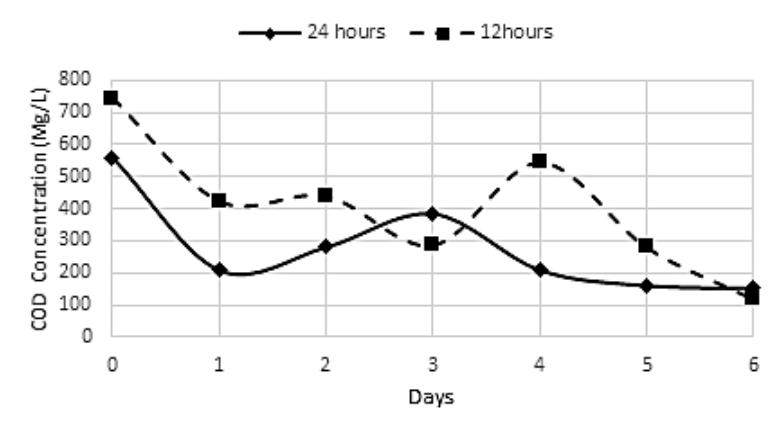

Figure 11. HRAR COD trend against illumination period

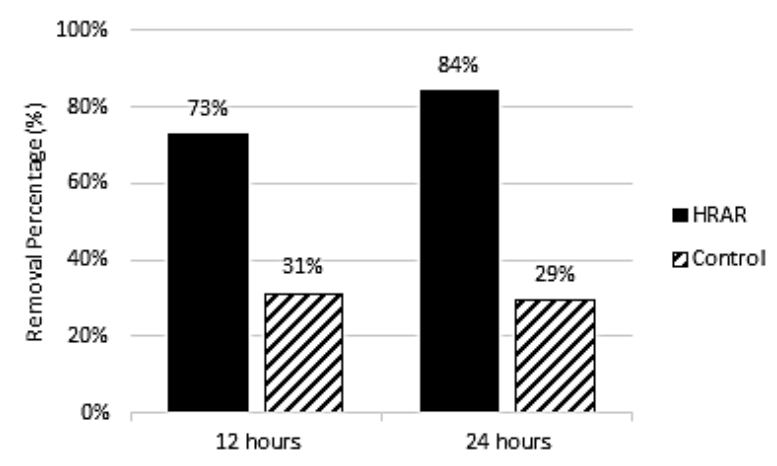

Figure 12. HRAR COD removal against illumination period

2009. Demonstration of Treatment System for Purification and Reuse of Laundry Wastewater. Bioresource Technology, 245 (1-3), 451-459.

4. Fallowfield, H. J. and Garret M. K. 1985. The Treatment of Wastes by Algal Culture. Journal of Applied Microbiology, 59 (14), 187S-205S.

5. Garcia, J., Mujeriego, R. and Marine, M.H. 2000. High Rate Algal Pond Operating Strategis for Urban Wastewater Nitrogen Removal. Journal of Applied Phycology, 12 (3), 331-339.

6. Hamouri, El B. 2008. How to Take Advantage of Combining High Rate Anaerobic Pre Treatment and High Rate Photosyntetic Post Treatment?. Department of Water Environment and Infrastructures Institute Agronomique et Veterinaire Hassan II, Rabat, Morroco

7. Ifeanyi V.O., Anyanwu B.N., Ogbulie J.N., Nwabueze R.N., Ekezie W., and Lawal O.S. 2011. Determination of the effect of light and salt concentrations on Aphanocapsa algal population, African Journal of Microbiology Research 5 (17), 2488-2492.

8. Kurniawan, Setyo Budi, Ipung Fitri Purwanti and Harmin Sulistiyaning Titah. 2018. The Effect of $\mathrm{pH}$ and Aluminium to Bacteria Isolated from Aluminium Recycling Industry. Journal of Ecological Engineering, 19 (3), 154-161.

9. Man, K. L., M. I. Yusoff, Y. and Uemura, J. Wei. 
2016. Cultivation of Chlorella vulgaris using nutriens source from domestic wastewater for biodiesel production: Growth condition and kinetic studies. Renewable Energy, 103, 197-207.

10. Mirquez, Liliana Delgadillo, Behnam Taidi, Dominique Pareau, and Filipa Lopes. 2016. Nitrogen and Phosphate Removal from Wastewater with a Mixed Microalgae and Bacteria Culture. Biotechnology Reports, 11, 18-26.

11. Mostret, E.S., and Grobbelar, J.U. 1987. The Influence of Nitrogen and Phosphorus on Algal Growth and Quality in Outdoor Mass Algal Culture. Biomass, 13 (4), 219-233.

12. Polpraset, C. 1996. Organic Waste Recycling. Asian Institute of Technology, Thailand.

13. Purwanti, Ipung Fitri, Setyo Budi Kurniawan, Harmin Sulistiyaning Titah and Bieby Voijant Tangahu. 2018. Identification of Acid and Aluminium Resistant Bacteria Isolated from Aluminium Recy- cling Area. International Journal of Civil Engineering and Technology, 9 (2), 945-954

14. Rawat, I., Kumar, R. Ranjith, Mutanda, T., Bux, F. 2010. Dual Role of Microalgae: Phycoremediation of Domestic Wastewater and Biomass Production for Sustainable Biofuels Production. Applied Energy, 88 (10), 3411-3424.

15. Tectona, Johan. 2011. The utilization of Pterocarpus Indicus as Activated Carbon for Laundry Wastewater Treatment. Bachelor Thesis, Department of Environmental Engineering, Institut Teknologi Sepuluh Nopember, Surabaya, Indonesia.

16. Vymazal, J., 1995. Algae and Element Cycling in Wetlands. Lewis Publisher, California

17. Wang, L.A, Min M., Li Y.C., Chen P., Chen Y.F., Liu Y.H. 2010. Cultivation of green algae Chlorella $\mathrm{sp}$. in different wastewaters from municipal wastewater treatment plant. Appl Biochem Biotechnol, $162,1174-86$. 